\title{
The Countermajoritarian Difficulty: From Courts to Congress to Constitutional Order
}

\author{
Mark A. Graber \\ University of Maryland School of Law; Department of Government and Politics, University \\ of Maryland, College Park, Maryland 20742-7215; email: mgraber@law.umaryland.edu
}

Annu. Rev. Law Soc. Sci. 2008. 4:361-84

First published online as a Review in Advance on August 11, 2008

The Annual Review of Law and Social Science is online at lawsocsci.annualreviews.org

This article's doi:

10.1146/annurev.lawsocsci.4.110707.172404

Copyright (c) 2008 by Annual Reviews. All rights reserved

$1550-3585 / 08 / 1201-0361 \$ 20.00$

\section{Key Words}

judicial review, democracy, accountability

\begin{abstract}
This review documents how scholarly concern with democratic deficits in American constitutionalism has shifted from the courts to electoral institutions. Prominent political scientists are increasingly rejecting the countermajoritarian difficulty as the proper framework for studying and evaluating judicial power. Political scientists, who study Congress and the presidency, however, have recently emphasized countermajoritarian difficulties with electoral institutions. Realistic normative appraisals of American political institutions, this emerging literature on constitutional politics in the United States maintains, should begin by postulating a set of democratic and constitutional goods, determine the extent to which American institutions as a whole are delivering those goods, and either explain how the political system as a whole might be redesigned to better deliver those goods or accept second-best constitutional goods that can actually be delivered by some attainable combination of political institutions.
\end{abstract}


The countermajoritarian difficulty is emigrating from the judiciary to the elected branches of government. Alexander Bickel, the Yale Law professor who coined the phrase countermajoritarian difficulty, regarded judicial review as "a deviant institution in the American democracy" (Bickel 1962, p. 18). Policy choices, he and other legal scholars of his generation proclaimed, were best made by elected officials who were politically accountable and more likely to reflect public sentiment than were unelected justices (see, e.g., Ely 1980). The titles of the books in the Institutions of American Democracy series sponsored by the Annenberg Foundation Trust challenge this consensus. Rosen's (2006) study, The Most Democratic Branch: How the Courts Serve America, celebrates the judicial capacity to reflect public opinion. "[T]he Supreme Court," he writes, "has followed the public's views about constitutional questions throughout its history" (p. 185). Rosen's historical survey finds that "unelected Supreme Court justices sometimes express the views of popular majorities more faithfully than the people's elected representatives" (Rosen 2006, p. 4). Mann \& Ornstein's (2006) work, The Broken Branch: How Congress Is Failing America and How to Get It Back on Track, suggests that the national legislature is the new "deviant institution in the American democracy." They complain about "the transformation of intense partisanship into virtually tribal politics," a "decline in accountability," "a decline in congressional deliberation and a de facto delegation of authority and influence to the president" (pp. x, 12). The result is a governing process that is not democratically sustainable. As Mann \& Ornstein (2006, p. 13) conclude, the "country and its enduring constitutional pact should not, and cannot, endure a broken branch for long."

This review documents how scholarly concern with democratic deficits in American constitutionalism has shifted from the courts to electoral institutions. The first section examines the increased tendency for political scientists to reject the countermajoritarian difficulty as the proper framework for studying and evaluating judicial power. Whittington (2007) in- sists that judicial supremacy is politically constructed by presidents who, more often than not, have reasons to empower courts as allies in their struggles against political rivals in the states, in Congress, and in their political party. Frymer (2007) discusses how judicial power was politically constructed by New Deal liberals eager to avoid taking responsibility for adjudicating clashes between labor and persons of color. Both Whittington and Frymer find politically constructed judicial review problematic, but not out of concerns with democratic majoritarianism. The second major section of the review documents the increased tendency for political scientists to emphasize countermajoritarian difficulties with electoral institutions. Hacker \& Pierson (2006) describe how political conservatives in a polarized polity are able to pass and maintain regulatory programs that lack broad popular support. Lee \& Oppenheimer (1999) explain why equal state representation in the Senate promotes undemocratic public policies that substantially overvalue the interests and values of small-state citizens. Such contemporary constitutional critics as Dahl (2001) and Levinson (2006) spend far more energy criticizing the majoritarian failings of Article I, Article II, and Article V than the democratic problems with life-tenured justices armed with the power to declare laws unconstitutional.

All the works surveyed abandon the subtle formalism underlying Alexander Bickel's original formulation of the countermajoritarian problem. Bickel (1962) insisted that elected officials should make political decisions because elected officials were politically accountable. Procedurally fair elections, his work indicated, were both the necessary and sufficient condition for democratic legitimacy (Bickel 1962, p. 33). Contemporary scholars of American politics recognize that political accountability is as determined by constitutional politics as constitutional forms. Works subtitled The Declining Importance of Elections (Ginsberg \& Shefter 1990) detail how procedurally fair elections are often not sufficient to give citizens adequate control over policymaking. Elections do not promote accountability, Hacker \& Pierson (2006, p. 217) 
explain, when voters are poorly informed or are not offered candidates committed to their values and interests. Litigation may promote accountability, Frymer (2007, p. 130) maintains, when courts provide de facto representation to political interests that elected officials have no incentive to accommodate.

This scholarship on the political foundations of judicial power, the baneful consequences of polarization on public policy, and the democratic deficits hard wired into the Constitution is generating a more systemic understanding of the countermajoritarian difficulty and constitutionalism in the United States. Commentators whose work was structured by Bickel's countermajoritarian problem isolated the Supreme Court from the rest of American politics, focused entirely on whether particular judicial decisions passed democratic muster, limited analysis to legal issues adjudicated by federal courts, and commented on only one dimension, majoritarianism, of democratic government. The works surveyed in this review observe that apparent democratic deficits in one institution may be consequences of democratic deficits in other institutions, explore how all American institutions respond to constitutional questions, elaborate how constitutional practices structure the ways political institutions make public policies, and suggest how judicial review may alleviate or aggravate coherence, polarization, bias, and accountability difficulties. Whittington, Frymer, Hacker \& Pierson, Lee \& Oppenheimer, and Levinson agree that the crucial constitutional question is whether the political system as a whole exhibits certain virtues, not whether a particular output or institution, standing alone, passes a particular democratic or constitutional standard. Realistic normative appraisals of American political institutions, this emerging literature on constitutional politics in the United States maintains, should begin by postulating a set of democratic and constitutional goods, determine the extent to which American institutions as a whole are delivering those goods, and either explain how the political system as a whole might be redesigned to better deliver those goods or ac- cept second-best constitutional goods that can actually be delivered by some attainable combination of political institutions.

\section{THE COUNTERMAJORITARIAN DIFFICULTY REVILED}

The contemporary countermajoritarian difficulty largely dates from the publication of Bickel's (1962) The Least Dangerous Branch: The Supreme Court at the Bar of Politics. In that work, Bickel famously declared that "when the Supreme Court declares a law unconstitutional, it thwarts the will of the representatives of the people of the here and now" (pp. 16-17). Although he declared that "this is what realistically occur[s]" (p. 17), Bickel later acknowledged that elected officials might approve of some judicial policymaking. What national officials thought about judicial decisions declaring state laws unconstitutional, in particular, was often unclear (Bickel 1962, p. 33). Nevertheless, Bickel (1962, p. 18) insisted, judicial review was a "deviant institution in a democratic society." The countermajoritarian problem, in his view (p. 33), was as much rooted in claims that policy ought to be controlled by elected officials as in claims that a majority of elected officials might not approve of judicial decisions.

Much political science wisdom for the past generation challenges the countermajoritarian perception of the relationship between justices and elected officials. The seminal works in this literature include Whittington (2007, 2005), Gillman (2006, 2002), Pickerill \& Clayton (2004), Clayton \& May (1999), Lovell (2003), Frymer (2003, 2007), McMahon (2004), Hirschl (2004), Ginsburg (2003), Sweet (2000), Graber (1993), Lasser (1988), and Dahl (1957). Several prominent law professors began working within and developing this new paradigm. They include Powe (2000), Balkin \& Levinson (2001), Friedman (1993, 2005), Griffin (1996), Tushnet (2006, 2005), and Klarman (2004). Important forthcoming works include Silverstein (2009), Clayton \& Pickerill (2009), Friedman (2009), and McMahon (2008). Students of public law committed to regime politics theory 
(Pickerill \& Clayton 2004) or the political construction of judicial power (Whittington 2007) explore why elected officials create, expand, or at least maintain the judicial authority to declare laws unconstitutional. Empirical investigation and positive analysis reveal that members of the dominant national coalition often promote their electoral prospects or preferred policies by supporting both judicial review and judicial supremacy. Justices impose majoritarian policies on outlier states, provide insurance when dominant coalitions suffer electoral defeats, enable elected officials to avoid taking firm stands on hotly contested political issues, provide a policymaking alternative when elected institutions are gridlocked, resolve issues lacking the political salience necessary to attract legislative attention, and facilitate position taking by announcing policies that crucial elites support but cannot publicly endorse. Elected officials sponsor judicial review by establishing and expanding federal jurisdiction, by nominating and confirming justices known to be willing to declare laws unconstitutional, by easing access to courts and providing resources to litigants who are making constitutional attacks on courts, by adopting procedures that enable litigants to discover and prove constitutional violations, by adopting vague statutory language that must be interpreted by courts, and by refusing to pass anticourt legislation in response to public attacks on courts.

Dahl's (1957, p. 291) claim that "it would appear, on political grounds, somewhat unrealistic to suppose that a Court whose members are recruited in the fashion of Supreme Court Justices would long hold to norms of Right or Justice substantially at odds with the rest of the political elite" states the central principle underlying this new conception of judicial power in a constitutional democracy. Neither Dahl nor any other scholar elaborating regime politics theory asserts that Supreme Court decisions perfectly reflect the platform of the political party that has won the most recent elections or that justices consistently select the policy favored by most citizens or politically influential actors. The argument is that at least some, of- ten shifting, subset of the lawmaking elite supports particular judicial decisions or the trend of judicial decision making. The judicial power to declare laws unconstitutional often privileges some members of the present lawmaking majority at the expense of others. Justices, for example, tend to support claims made by members of the presidential wing of the dominant national coalition when constitutional disputes arise between the executive and legislative branches of the national government (Whittington 2007, p. 295; Graber 2006a, p. 691). What courts hardly ever do is protect powerless minorities that have no champions among the powerholding majority.

During the first part of the present decade, several younger political scientists wrote important first books documenting the political construction of judicial power (Graber 2005 discusses these works at length). Lovell (2003) detailed how antiunion decisions handed down by the Supreme Court during the first third of the twentieth century were consequences of legislative compromises that facilitated judicial policymaking in the guise of statutory interpretation. McMahon (2004) explored how members of the Roosevelt, Truman, and Eisenhower administrations paved the way to Brown v. Board of Education (1954) by packing the federal courts with racial liberals and sponsoring litigation challenging Jim Crow policies. Comparative law scholars demonstrated that the political construction of judicial review was a worldwide phenomenon that had similar causes and raised similar concerns as judicial empowerment in the United States. Elected officials on every major continent, researchers found, were responsible for instigating and maintaining a "global expansion of judicial power" (Tate \& Vallinder 1995). Hirschl (2004) detailed how constitutional politics in new constitutional societies were driven more by elites seeking to preserve power than by altruistic concerns with the rights of the poor and disadvantaged. Ginsburg (2003) documented how judicial review in new democracies was conceptualized as a form of insurance for existing elites, rather than as a check on their power. 
These studies of judicial power in the United States and abroad repeatedly emphasized how judicial power fed on political fragmentation. The more diffuse political power, the more likely courts resolved and were invited to resolve important constitutional issues. "[P]olitical diffusion is good for judicial power," Ginsburg's (2003, p. 261) analysis of judicialization in Mongolia, Taiwan, and South Korea noted. He observed how "[p]olitical diffusion creates more disputes for courts to resolve and hinders authorities from overruling or counterattacking courts." Judicial review survived in the United States in part because fissures within the Jeffersonian coalition inhibited attacks on the Federalist-dominated judiciary (Ellis 1971). The American Supreme Court decided such cases as Roe v. Wade (1973) and Dred Scott v. Sandford (1856) in part because abortion and slavery raised cross-cutting issues that could not be resolved within the existing party system (Graber 1993).

Two important books by more senior scholars extend and significantly enrich the political regimes model of the interaction between justices and elected officials. Both Whittington (2007) and Frymer (2007) take the political construction of judicial power for granted. "For constitutions and institutions like judicial review to exist in historical reality," Whittington (2007, p. 4) states, "there must be political reasons for powerful political actors to support them over time." Neither author regards the countermajoritarian difficulty as having much explanatory power or normative force. Whittington meticulously details how presidential ambitions and political fragmentation have promoted the growth of judicial power in the United States. Although a few presidents have had political incentives to attack courts, presidents more often seek judicial support in their struggles to overcome the political fragmentation of American society. "Federalism, separation of powers, and the particular structure of the American party system," Whittington (2007, p. 289) states, "have played key roles in encouraging presidents to lend their support to the courts." Frymer (2007) painstak- ingly describes how legislative choices and political fragmentation help explain the judicial decisions that desegregated labor unions. Liberals during the 1950s and 1960s, eager to avoid responsibility for mediating tensions between white workers and the civil rights movement, doled out responsibility for adjudicating debates over employment relations to administration agencies and responsibility for adjudicating racial issues to the federal courts. The resulting "patchwork state" (Skowronek 1982, pp. 45-46) has significant failures, but none is adequately captured by the countermajoritarian difficulty.

\section{Political Foundations of Fudicial Supremacy}

Political Foundations of Judicial Supremacy: The Presidency, the Supreme Court and Constitutional Leadership in U.S. History is the rare work likely to be considered a seminal study for at least three important and growing research agendas in law, political science, and history. Whittington (2007) in less then 300 pages brings conceptual order to the burgeoning literature on the Constitution outside of the court, identifies crucial patterns in the political construction of judicial review, and brilliantly elucidates the growth of judicial power in the United States. Much previous scholarship (Burgess 1992, Curtis 2000, Devins 1996, Dinan 1998, Fisher 1988, Friedman 1993, Levinson 1988) had detailed how other political actors often engaged in constitutional interpretation, sometimes challenging (Agresto 1984, Kramer 2004) and sometimes buttressing (Graber 1993, Lovell 2003) judicial authority. Friedman's (1998, 2000, 2001, 2002a,b) magnificent work on the history of the countermajoritarian difficulty chronicles the nature of political opposition and support for judicial power throughout American history. Friedman aside, that past work treated as episodic presidential assertions of constitutional authority or political invitations for courts to make constitutional policy. Commentators noted that several presidents had attacked judicial supremacy, 
but they failed to explain why some presidents challenge courts while others ally themselves with the federal judiciary. History tended to repeat itself, without any development. Edwin Meese's (1987) attack on judicial supremacy was interpreted as nothing more than a mere variation on themes first played by Thomas Jefferson (1975, pp. 562-63). Whittington (2007) offers a far more sophisticated view of the practice of constitutionalism outside the court, judicial supremacy, and the political construction of judicial power. Political Foundations demonstrates that presidents compete with courts for the authority to determine constitutional meanings only in relatively rare historical circumstances. Presidents in more common political circumstances have substantive incentives to bolster judicial authority. Whittington (2007, p. xi) notes that "[d] epartmentalism has enjoyed moments of prominence in American constitutional thought and practice," but his work details how "[p]residents and political leaders have generally preferred that the Court take the responsibility for securing constitutional fidelity." The tools presidents have for engaging in both practices have changed over time. Nineteenthcentury presidents, working within a relatively thin institutional environment, could challenge judicial pretensions in ways politically unavailable to their twentieth-century descendants. The more general presidential tendency to empower courts provides far stronger foundations for judicial authority at present than Marbury $v$. Madison (1803). Paradoxically, the political institution commonly thought to be the best vehicle for a popular constitutionalism, Whittington's exceptionally important study finds, is, in fact, largely responsible for entrenching judicial supremacy in the United States.

Judicial supremacy in the United States has been challenged only after reconstructive presidents gain office. These presidents, Jefferson, Jackson, Lincoln, Roosevelt, and Reagan, have electoral permission to uproot the previous constitutional order. They challenge inherited understandings of the proper division of consti- tutional power between governing institutions and the proper limits on constitutional power. ${ }^{1}$ Reconstructive presidents typically perceive a judiciary staffed by holdovers from the previous regime as their main rival for constitutional authority. Their capacity to transform the political order requires them to undermine the Supreme Court's privileged place as a constitutional interpreter. Whittington (2007, p. 74) points out, "As the old regime collapses, the judiciary is likely to be both a visible defender of the old order and one that survives electoral turnover." For this reason, judicial supremacy "is a likely target for a reconstructive leader seeking to dismantle the previous regime." The resulting presidential attacks on the federal judiciary are as rooted in constitutional conviction as in political interest. In sharp contrast to critics of departmentalism (i.e., Alexander \& Schauer 1997), who insist that judicial supremacy is necessary because politics is normally unprincipled, Whittington (2007) notes that attacks on judicial supremacy in the United States take place only during those rare historical moments when issues of constitutional principle become most salient politically. In his view, "When the political debate begins to focus on the 'constitutional baseline' itself, judicial authority becomes more tenuous and other political actors make stronger claims to interpretive primacy" (p. 22).

Presidents become attracted to judicial power when the role of constitutional principle in politics wanes. Affiliated presidents, who seek to maintain the constitutional vision of and the political coalition forged by the most recent reconstructive president, inherit a sympathetic Court. Whittington (2007, p. 87) observes, "Affiliated leaders will expect to place like-minded judges on the bench and can expect that earlier affiliated [and reconstructive] leaders did the same." The Supreme Court had a Jacksonian majority when Martin $\checkmark$... Buren took office. Roosevelt bequeathed

\footnotetext{
${ }^{1}$ Skowronek (1993) is the classic study of reconstructive, affiliated, and preemptive presidents, as well as the conception of political time.
} 
Truman a federal judiciary staffed almost entirely by New Dealers. Such presidents find empowering their allies on the federal bench a useful means for "regime elaboration and enforcement" (Whittington 2007, p. 117), particularly "against constitutional outliers" (p. 105) in recalcitrant states, "cut[ting] through the legislative gridlock to achieve results consistent with regime commitments" (p. 126), and for "generat[ing] position-taking opportunities by reducing the policy responsibility of the elected officials" (p. 137). Preemptive presidents, who do not identify with the most recent reconstructive president, are nevertheless not in a position to challenge judicial authority. Confronting a Congress controlled by political rivals, Grover Cleveland and William Clinton often found judicial decision making the lesser of two evils. "In a hostile political environment," Political Foundations (pp. 166-67) points out, "the law and the judiciary may be the best defense that a president has." Justices who have established precedents favoring executive power when affiliated presidents were in office may be less tempted by short-term benefits to modify those rules during the relatively short interregnum of preemptive rule. Whittington (2007, p. 169) declares, " $[\mathrm{H}]$ aving embraced broad theories of inherent presidential powers, judges are unlikely to hedge them simply because they are being exercised by oppositional presidents."

These patterns of presidential assertiveness and passivity have developed as well as cycled. As politics alternated between reconstructive, affiliated, and preemptive presidents, judicial power in the United States became more deeply entrenched. Reconstructive presidencies rarely occur (Whittington 2007, p. 50), and they have short windows of opportunity. Affiliated and preemptive presidencies are far more common. The resulting ratio of presidents who challenge judicial authority to presidents who support judicial authority has over time generated legal and political precedents that increasingly strengthen political assertions of judicial supremacy while rendering political challenges to judicial supremacy more difficult. Presidential challenges to judicial authority over time weakened considerably as deferential precedents made by affiliated and preemptive presidents accumulated. Whittington details how Rooseveltian and Reaganite challenges to the Court were far tamer than nineteenthcentury departmentalist claims, in large part because there was a greater encrusting of judicial supremacy to overcome. Lincoln declared he would not treat the Dred Scott decision as limiting federal power. Roosevelt sought only to secure more favorable judicial decisions. His "proposal to pack the Court with his supporters," Whittington (2007, p. 266) correctly states, "contained no provision requiring judicial restraint at all." The Reagan attack on courts was limited largely to a few symbolic speeches. Constrained by the now overwhelming precedential support for judicial power, $P_{0-}$ litical Foundations observes, presidents "reserve the right to complain and cajole, but they do not claim the authority to say what the Constitution means" (p. 284).

An institution that routinely promotes presidential ambitions is no more countermajoritarian than the presidency. During the 181 years in which the United States has been governed by affiliated or preemptive presidents, members of the executive department have enthusiastically supported the course of judicial policymaking, aggressively promoted judicial power, or, at a minimum, preferred judicial decisions to legislative supremacy. Only 5 of the 43 American presidents have challenged the judicial authority to declare laws unconstitutional, and their departmentalist assertions did not have a long shelf life. As reconstructive presidents transformed the courts through the normal appointment process, concerns with judicial supremacy dissipated. Jackson, Lincoln, and Roosevelt all abandoned contests for constitutional authority late in their terms of office. The Supreme Court has declared neither more laws nor more important laws unconstitutional during reconstructive presidencies. Whittington (2007, p. 158) notes, "[J]udges are often [most] activist when their apparent friends occupy the corridors of legislative power." This steadily increasing tendency for presidents to empower courts 
suggests that had the justices refrained from declaring laws unconstitutional throughout most of American history, that would have been the course that would have "thwarted the will of the representative[ ] of the people of the here and now" in the White House. Political Foundations appropriately concludes, "The American historical experience shows politicians actively helping to construct judicial authority. They are not the victims of judicial supremacy" (p. 290).

The countermajoritarian difficulty does not even describe the relationship between courts and elected officials in the national government when reconstructive presidents hold office. Reconstructive presidents challenge the Supreme Court's authority over constitutional meaning as part of wide-ranging efforts to transform the entire regime. "Conflicts with the courts," Whittington (2007, p. 59) states, "are only a single skirmish within the larger presidential offensive to establish his authority to remake American politics." Jackson had to contend with both the Marshall Court and the proto-Whigs who controlled at least one house of Congress from 1828 until 1834. Roosevelt struggled against both the Nine Old Men and the southern Democrats who held crucial levers of power in both houses of Congress during the 1930s. Jacksonian and New Deal challenges to judicial power faltered when opposition forces in the national legislature defeated efforts to reconstruct the federal judiciary. Proponents of the national bank and protective tariffs in 1831 easily defeated a southern Jacksonian proposal to abolish federal appellate jurisdiction over state court decisions interpreting the federal Constitution (Warren 1913). Southern Democrats, fearing that Roosevelt would appoint racial liberals to the federal bench, helped defeat the Court packing plan in 1937 (McMahon 2004). This underlying political support for judicial power suggests that the Supreme Court even during reconstructive presidencies does not "thwart the will of a majority of the representatives" in at least one elected branch of the national government. At the very least, a majority in at least one elected branch of the national government has historically thought government by judiciary more attractive politically than presidential authority to determine constitutional meanings.

Reconstructive presidencies in their pure form may also be a relic of the American constitutional past. Skowronek (1993, p. 443), who developed the presidential typology that structures Political Foundations, suggests "discarding the idealized reconstructive catharsis as a premise for leadership." In his view, presidents have less and less capacity to transform the constitutional order as the political system becomes increasingly fragmented and rival political actors develop independent power bases. "The greater security of institutions and political actors throughout the system," Skowronek (2008, pp. 114-15) observes, presently "seems to encumber the ambitions of reconstructive leaders." The Reagan Revolution was blunted in part by entrenched understandings of judicial power, but also by entrenched Democratic majorities in the House of Representatives that easily parried assaults on their allies in the federal judiciary. Should the "waning of political time" (Skowronek 1993, p. 407) continue and government institutions grow "ever thicker" (p. 413), the probability increases to a near certainty that opposition political leaders will maintain enough control over at least one elected branch of the national government to prevent reconstructive presidents from fully wresting authority over constitutional meaning from the courts. Judicial decision making under such conditions of political fragmentation will raise democratic problems, but these problems are not well captured by the countermajoritarian difficulty.

\section{Black and Blue}

Black and Blue: African Americans, the Labor Movement, and the Decline of the Democratic Party details some of the democratic problems with politically constructed judicial review. Frymer's (2007) fascinating study of the relationships between the civil rights and labor movements during the second half of the twentieth century successfully challenges both the consensus 
view in political science (i.e., Rosenberg 1991) that courts cannot bring about significant social change and the consensus view in the legal academy (i.e., Chayes 1976, Fiss 1979) that courts are desirable agents for significant social change. His path-breaking scholarship provides a far more nuanced understanding of the role litigation plays in American political and constitutional development. Judicial decisions matter, but for reasons that confound scholars and policy activists. Supreme Court decisions do not "thwart the will of the representatives of the people of the here and now" as Bickel thought, but make a greater contribution to policy incoherence than legal scholars suspect.

Frymer's story begins with African Americans seeking entry to labor unions. Entry was desirable because labor unions in the early to mid-New Deal order promised members both economic security and political power. Entry was problematic because desegregation pitted white workers who were staunch members of the Roosevelt coalition against persons of color who were giving an increasing share of their vote to Democrats. Leading New Dealers and proponents of the Great Society sought to avoid politically painful choices by established separate governing regimes. "By the 1960s," Frymer (2007, p. 3) explains, "instead of one national labor policy, the federal government had two, each with its own regulatory agency, its own understanding of workplace politics, and ultimately very different understandings of democracy." The National Labor Relations Board (NLRB) was given responsibility for determining labor policy. Federal courts were empowered to determine civil rights policy.

Elected officials, Frymer's research concludes, authorized courts to mediate between labor and persons of color. Political liberals on both sides of the aisle self-consciously foisted civil rights issues onto the federal judiciary during the 1960s by expanding access to the courts, authorizing the Justice Department to sue on behalf of African Americans, and providing special incentives for lawyers litigating claims of racial discrimination. Senator Hugh Scott spoke for legislative majorities when he declared, "Congress should encourage citizens to go to court in private suits to vindicate its policies and protect their rights. To do so, Congress must insure that they have the means to go to court and to be effective once they get there" (quoted in Frymer 2007, p. 86). Liberal representatives had previously sharply improved federal judicial capacity to manage complex litigation. Black and Blue points out how Congress during the 1940 s and 1950 s authorized legal elites to take numerous steps that would make adjudication an attractive means for making policy. "[E]lected officials," Frymer (2007, p. 76) asserts,

\begin{abstract}
delegated power to judges and lawyers to greatly expand legal institutions, making litigation a more appealing political strategy for civil rights groups. The reform of the rules of federal civil procedure at this time resulted in a number of important advances. It expanded the opportunities for civil rights groups to gain standing and access to a judge; expanded the entry points at which civil rights groups promoted creative legal interpretations through reforms to venue and jurisdiction; made it easier for civil rights plaintiffs to "discover" damaging evidence of discrimination; gave judges the power to create "special masters" to oversee and implement court orders; and gave the judges far greater influence in determining their remedies, particularly financial, to use against resistant discriminators.
\end{abstract}

Few reforms were adopted with the civil rights movement consciously in mind. Nevertheless, civil rights litigators took advantage of the resources elected officials made available to politically empowered federal courts when discovering evidence of racism in unions and fashioning creative remedies for illegal discrimination.

Frymer documents a seeming liberal success story. Contrary to Rosenberg (1991) and others (i.e., Horowitz 1977), litigation secured substantial social reform. Controversial judicial decisions are implemented, Black and Blue details, when judicial losers cannot rally sufficient 
political support and those decisions impose substantial financial burdens. Federal courts during the 1960s mandated enormous fines for past discrimination, which attracted lawyers to civil rights causes and threatened to bankrupt racist unions. The result was a good deal of litigation, a good amount of compensatory damages, and a good deal more integration than existing models suggest litigation capable of achieving. Unions caved under the financial pressure. As one reluctant labor lawyer informed his clients, "[W]e must face the fact that unless we do what the law requires we will be bled to death financially" (Frymer 2007, p. 91). By the end of the civil rights era, Frymer (2007, p. 94) establishes, "courts had successfully integrated large swaths of the American labor movement."

Black and Blue scoffs at claims that democratic norms were violated when the federal judiciary integrated unions. Persons of color sued for damages under statutes passed by Congress, Congress enabled them to bring suit by loosening standing rules and providing attorneys' fees for lawyers, and the resulting lawsuits were typically decided by justices placed on the federal bench in part because of perceived sympathy with the civil rights movement (Frymer 2007, pp. 76, 86; Gillman 2006). The postNew Deal constitutional order suffered from democratic deficits, but not because justices had policymaking responsibility. Frymer (2007, p. 133) maintains, "All branches of the American state-electoral, administrative, and judicial - are fundamentally flawed in their ability to effectively represent the will of the public.” Judicial policymaking in civil rights cases alleviated some of these democratic deficits. "Democratic equality will often necessitate action by those who are less directly representative to the public," Frymer (2007, p. 130) declares, "because they have incentives to represent both minority and majority groups that are unable to represent themselves effectively."

Nevertheless, the litigation campaigns that desegregated unions had unanticipated costs for persons of color. In Black and Blue Frymer (2007, p. 2) details how " $[t]$ he increase in black union membership was accompanied by a significant decline in the size and influence of the labor movement." Labor unions could be integrated only by means that weakened their political and economic capacities. Judicial decisions that endorsed the legal claims of the civil rights movement widened the political gulf between union members and persons of color, two vital liberal constituencies. Faced with liberal politicians unwilling to side with labor and liberal justices who enthusiastically sided with the civil rights movement, many white union members turned to more conservative politicians for relief. Persons of color were the immediate beneficiaries of political efforts to channel labor disputes to the courts, but white workers who defected from the Democratic Party unwittingly empowered antiunion employers in the long run. Republican Party electoral victories, made possible in part by a politically enfeebled union movement, "allowed Republican presidents to change the composition of the NLRB, leading to the overturning of dozens of labor doctrines which ... are... critical to the massive decline in union power" (Frymer 2007, p. 4). Federal court decisions favoring persons of color more directly damaged unions. Judicial orders mandating integration often took "broader powers away from unions ..., powers that were often critical to union power such as seniority and hiring autonomy" (Frymer 2007, p. 97). Thus, when facilitating black entry into labor unions, liberal justices undermined labor unions as a vehicle for black economic and political power. This subversion of union power was not wholly unintended. Civil rights litigation was often sponsored by lawyers with little interest in protecting the interests of workers. "The use of corporate lawyers to fight union racism," Frymer (2007, p. 7) claims, "often served the dual agenda of expanding civil rights and... weakening the chief opposition to free market capitalism."

The judicial decisions that integrated unions raise important normative questions about the role of courts in a constitutional democracy other than the countermajoritarian difficulty. Frymer's primary concern might be labeled the 
coherence difficulty. The federal judiciary and the NLRB were entirely separate institutions whose decisions on labor relationships were not coordinated by any more central agency. The consequence of this fragmentation was that judicial decisions promoting integration often undermined NLRB rulings thought vital for maintaining union capacity to advance the concerns of working people. "U.S. national labor policy" by "divid[ing] labor and race into separate forums," Black and Blue explains, fostered "conflict instead of intersection" (Frymer 2007, p. 9). Supreme Court policymaking in the civil rights era also presented polarization difficulties. Justices managing the integration of unions worried more about which party made better legal arguments than about satisfying all important constituencies. Frymer (2007, pp. 136-37) points out that "[u]nlike regulatory agencies that are designed to reach compromises between antagonist interest groups, courts tend to provide 'winner-take-all' outcomes that benefit individual litigants." The very possibility of achieving the "full loaf" (Warren 1977, p. 6) through litigation inhibited bargains between workers of different races, all of whom would have benefitted in the long term by mutual concessions.

Black and Blue concludes by demonstrating how judicial policymaking raises bias difficulties. Which governing institution resolves political controversies matters, even when no available decision-making process is more majoritarian than the alternatives. Frymer points out that justices trained in law often reach different decisions than other governing officials who rely on different decision-making logics. His examination of disputes that arose during labor elections finds that courts were more inclined to see any racist remark as raising questions about the legality of prounion campaigns, whereas administrative agencies were more concerned with the underlying racial politics. In sharp contrast to "federal court decisions under antidiscrimination law," Frymer (2007, p. 110) writes, "racism in labor law is regulated for its potentially damaging political consequences, and not because it is considered rep- rehensible and unacceptable in any context." Given the past history of discrimination in unions, that workers would make some racial appeals during union elections is hardly surprising or unhealthy (Frymer 2007, p. 119).

Accountability difficulties might be added to this list of concerns with judicial power in a constitutional democracy. Elected officials who divert political controversies to the courtroom mask their responsibility for the ultimate judicial decision. "When legislators shift divisive social issues to the judicial branch because they want to avoid electoral accountability for making hard choices," Lovell \& Lemieux (2006, p. 144) point out, "their actions raise significant concerns about democratic accountability." A regime characterized by "the simultaneous operation, or intercurrence, of different political orders" (Orren \& Skowronek 2004, p. 17) presents additional accountability difficulties when citizens cannot determine what institutions are responsible for offensive policies and what political actions are necessary to bring about desired reforms. Patchwork states promote pluralism (see Peretti 1999), but also privilege elite interests by making the coordinated action necessary to secure social reform exceptionally difficult (Graber 2001).

Whether politically constructed judicial review presents distinctive accountability, coherence, polarization, and bias difficulties is contestable. Legislators who sought to achieve the Great Society by facilitating litigation did not escape the wrath of voters. White workers who blamed liberal justices for integrating their unions abandoned the Democratic Party in droves during the late 1960s and afterwards (Frymer 2007, p. 4; Greenberg 1996). Coherence was a problem with numerous New Deal and Great Society policies that farmed policymaking responsibilities out to separate institutions with different constituencies, whether or not courts were involved (Lowi 1969). Frymer (2007, p. 14) recognizes that "multiple agencies, created at different times to address different problems, ... all attempting to address the same issue in fundamentally different ways,... working at cross-purposes 
and producing inefficient and conflicting policies" are a common feature of "American state building." Justices are quite frequently accused of inhibiting legislative compromises (see McCloskey 2005) when the only compromise elected officials are able to reach is to transfer policymaking responsibilities to courts (Graber 2006b, pp. 33-35). Parties may run to the courtroom because justices are more willing to make controversial constitutional decisions than elected officials, not because they are seeking to avoid bargaining with political rivals. That both union members and persons of color might have benefitted in the longer run by greater legislative accommodation does not entail that elected officials acting without the possibility of judicial review in the background could have reached a satisfactory arrangement. Generalizing about judicial biases from one set of legal decisions handed down at a particular time is always problematic. Federal courts staffed by legal liberals exposed to critical race theory (see, i.e., Delgado 1995, Matsuda et al. 1993) in law schools during the 1980s and 1990s might have been more sensitive to the political dimensions of racist speech than liberal justices educated during the heyday of the American Civil Liberties Union. The polarizing tendency of courts may also have been rooted in the legal liberalism of the civil rights era rather than in more enduring judicial tendencies. During the period from the New Deal to the Great Society, constitutional politics was structured by centrist parties and polarizing courts. When students of American politics at the turn of the twenty-first century complain about polarization and democratic deficits, their target is typically elected officials and the elected branches of the national government.

\section{THE COUNTERMAJORITARIAN DIFFICULTY REVIVED}

Students of Congress and the presidency, without ever citing Bickel, are increasingly identifying countermajoritarian difficulties in American electoral politics. American politics, research insists, is not the pluralist bazaar de- picted by the previous generation of political scientists (i.e., Dahl 1961), in which almost all major social interests are accommodated to some degree. Electoral politics in the United States suffers from severe democratic deficits. Abandoning inherited concerns with whether centrist parties could produce coherent policies (Am. Polit. Sci. Assoc. 1950), scholars at the turn of the twenty-first century worry that polarized parties are adopting platforms that fail to resonate with average citizens. The Constitution, prominent works (Dahl 2001, Levinson 2006) insist, aggravates the countermajoritarian tendencies of contemporary American politics. Article I undemocratically skews public policy by mandating equal state representation in the upper chamber of the national legislature, Article II vests too much power in an insufficiently accountable executive, and Article $V$ prevents popular majorities from adopting more democratic governing institutions.

The political construction of judicial review places these democratic failings in a different perspective than the countermajoritarian problem. Bickel and his followers compared and contrasted courts and legislatures as democratic fora. Most concluded that Congress was the superior site for majoritarian policy (i.e., Ely 1980; Choper 1980, pp. 4-59) but some (i.e., Shapiro 1966, pp. 17-26; Peretti 1999) disagreed. This contrast is inappropriate when elected officials empower courts to secure political goals. What needs to be explored and evaluated is the democratic propriety of various quasi-alliances between the justices and at least some members of the dominant electoral coalition. Superficial examination suggests politically constructed judicial review sometimes aggravates and sometimes compensates for democratic deficits in other institutions. If, for example, an off-center president and malapportioned Senate are both more conservative than most voters, then justices nominated by the president and confirmed by the Senate will increase polarization tendencies in American politics. If, however, an off-center president is more conservative than the general public and a malapportioned Senate is more liberal then the general public, then 
courts may actually improve the democratic performance of governing institutions.

\section{The Countermajoritarian Difficulty with Congress and the Presidency}

Polarization is the buzzword for describing contemporary American politics. Both Republicans and Democrats are more united internally than at any other point in history and more distinct from each other (McCarty et al. 2006, pp. 23-24). Liberal Republicans are extinct. Conservative Democrats are high on the endangered species list. Polsby (2004, p. 154) details a "movement away from a long-standing conflict between the two majorities, congressional and Democratic, and toward a situation in which the main competing coalitions have been effectively mobilized by each of the two dominant parties." "Conservative and liberal," McCarty et al. (2006, p. 3) state, "have become almost perfect synonyms for Republican and Democrat." The parties are also polarized on more issues than ever before. Carsey \& Layman (2005, p. 1) detail the process of "conflict extension" in the United States. Racial and foreign policy issues had historically crosscut the New Deal party system. At present, they note, "the parties are sharply divided on all of the major policy dimensions in American politics: economic and social welfare issues, racial and civil rights issues, cultural issues such as abortion and gay rights, and defense and foreign policy issues."

This partisan polarization does not reflect any underlying polarization of the general electorate. Prominent social scientists insist that no fundamental change has recently taken place in public opinion. Fiorina et al. $(2005$, p. 8$)$ declare, "[T]here is little evidence that Americans' ideological or policy positions are more polarized today than they were two or three decades ago." The cultural war, in their view, is fought almost entirely by a small class of partisan activists. Americans appear to hold more extreme positions than they actually do because on election day they are offered only the choice between two relatively immoderate parties. "Even if they still are centrists," Fiorina and coauthors
(2005, p. 114) complain, "voters can choose only among the candidates who appear on the ballot and vote only on the basis of the issues that are debated." Other prominent political scientists insist that polarization in the citizenry is more widespread. Abramowitz \& Saunders (2005, pp. 4-5) found that "partisan polarization has increased considerably over the past decade," and "is not confined to a small group of leaders and activists." Nevertheless, they agree that parties are far more polarized than the general electorate. Although they find "sharp divisions between supporters of the two major parties that extend far beyond a narrow sliver of elected officials and activists," Abramowitz \& Saunders (2005, p. 19) acknowledge that "most Americans are moderate in their political views."

This polarization is having important policy consequences. Some political reforms are being stifled by gridlock. " $[\mathrm{P}]$ olarization in the context of American political institutions," McCarty et al. (2006, p. 3) assert, "now means that the political process cannot be used to redress inequality that may arise from nonpolitical changes in technology, lifestyle, and compensation practices." More surprisingly, political extremists in the Republican Party have successfully navigated the polarized political universe and made much of their political vision of the law of the land. Conventional political science models predict that polarized politics should nevertheless generate centrist policies, as the few remaining centrists in each party control the political agenda (Hacker \& Pierson 2006, p. 2). Moving off an unpopular veto point is difficult, but whatever movement takes place should be toward the center. Political conservatives are defying what was thought to be this first law of political thermodynamics. American politics moved considerably during the Bush administration, but that movement has been to- * ward the extremes rather than the center.

Hacker \& Pierson (2006) document the partisan, countermajoritarian consequences polarization is having on contemporary politics. Their Off Center: The Republican Revolution \& the Erosion of American Democracy explains why 
constitutional and political protections for centrist politics no longer function in the United States. "[O] ur vaunted system of representation has shifted off center," they declare, "and ... the normal guardians of democratic accountability have not been up to the task of bringing it back" (Hacker \& Pierson 2006, p. 69). Conservative Republicans have combined aggressive organization, enormous financial support, and deceptive political advertising to produce economic programs that most Americans oppose. Federal courts play only a bit role in this powerful indictment of the contemporary American regime. Hacker \& Pierson (2006, pp. 106, 190) briefly note that "since 1994, the Court has been striking down federal laws at an unprecedented rate" and complain that such decisions as Buckley v. Valeo (1976) inhibit desirable campaign finance reform. What Off Center relentlessly details is how contemporary political parties and elected officials, the very institutions and persons thought to guarantee a majoritarian centrist politics, now in practice facilitate increased rule by affluent minority extremists. American politics is presently structured by a "stark disconnection between the public and elites" (Hacker \& Pierson 2006, p. 223), but that division is between voters and partisan leaders rather than between elected officials and unelected justices.

Polarization in the United States, Hacker \& Pierson document, is largely a consequence of dramatic increases in the conservatism of $\mathrm{Re}$ publican elites. Republican Party leaders over the past generation have become far more conservative than the general public. Democratic Party leaders are no more liberal than the general public than they were when Richard Nixon was president (Hacker \& Pierson 2006, p. 27). The average Republican in Congress is now far more conservative because very conservative Republican representatives have replaced less conservative Republican representatives. The average Democrat in Congress is only slightly more liberal because conservative southern Democrats were replaced by very conservative southern Republicans. Republican representatives from Midwest states vote more conservatively than they did 30 years ago, but Democrats from New England vote no more liberally than during the 1970 s (Hacker \& Pierson 2006, p. 29).

The increased conservatism of the Republican Party does not correspond with any increased conservatism in the general electorate. No prominent study demonstrates any general rightward trend in public attitudes. Hacker \& Pierson's (2006, p. 40) analysis of the political science literature asserts that "one is hard pressed to find any evidence that Americans are markedly more conservative today than they were in the recent (and even relatively distant) past." Public opinion research finds no increase in support for particular Republican policies. When asked at the onset of the Bush administration what should be done with the surpluses gained during the Clinton administration, overwhelming majorities advocated new spending programs (Hacker \& Pierson 2006, pp. 50-51). Instead, Republicans passed a major tax cut that mostly reduced the tax burdens of the wealthiest Americans. That tax cut, Hacker \& Pierson (2006, p. 50) maintain, is an egregious instance of countermajoritarian policymaking. "Americans," they assert, "didn't think tax cuts were particularly important in 2000 and in 2001," they "didn't want to spend massive sums on tax cuts, nor did they want the tax cuts to benefit the rich disproportionately" (p. 50).

Off Center contends that countermajoritarian policymaking is being enabled by almost every trend in American politics. "The cords of accountability have weakened," Hacker \& Pierson (2006, p. 17) forcefully argue, "because the electoral map has sorted into safely Republican and Democratic districts," "because of rising incumbency advantage," "because of the growing importance of money in the electoral arena," "because of the growing inequality of resources and organization between the rich and the rest," and "because of the deliberate efforts of political elites to make it hard for Americans to know what they are up to." Rising economic inequalities are the main villain in this political morality tale. Hacker \& Pierson (2006, p. 114) cite and endorse studies finding that "congressional 
voting and public policy are more responsive to the opinions of high-income citizens than poorer voters" (McCarty et al. 2006, p. 73). Money skews Republican and Democratic priorities in different ways. Off Center notes, "[W]hile both parties have felt compelled to mobilize higher-income citizens, the Republicans have found the goal much more consistent with their aims" (Hacker \& Pierson 2006, p. 115). Affluent Republicans aggressively promote economic policies that skew benefits to the most fortunate Americans. Affluent Democrats, by comparison, have some tendency to "blunt[ ] the traditional populist rhetoric of the party" (Hacker \& Pierson 2006, p. 115). Hacker \& Pierson (2006, p. 171) point out, "Important elements of the standard Democratic agenda, especially on economic issues, coexist awkwardly with the realities of contemporary political finance, which require that Democrats seek support from deep-pocketed business contributors." ${ }^{2}$ Their need for the enormous sums necessary for contemporary political campaigns helps explain why Republicans in office are more committed to redistributing resources to the affluent than the average Republican voter and Democrats in office are less committed to redistributing resources to the poor than is the average Democratic voter.

Controlling the national government and possessing the wherewithal to flood the media with their interpretation of political events, affluent conservatives consistently confuse the public about legislation that has actually been passed and executive policies that have been

\footnotetext{
${ }^{2}$ Affluent Democrats seem more inclined to be social liberals than economic liberals. Thus, the Clinton administration promoted off-center policies on matters such as partial-term abortions, while adopting center, if not center-right, economic policies (Graber 1997, pp. 731-33). Similarly, Republicans have not successfully implemented their social agenda because "[i]n contemporary politics, opposition to conservatives on cultural and social issues is intense, organized, and well heeled" (Hacker \& Pierson 2006, p. 195). Indeed, contemporary American politics might be characterized as structured by a conflict between affluent citizens who fight to the death for off-center economic policies, but cave on abortion, and other affluent citizens who fight to the death for offcenter abortion policies, but cave on tax policies.
}

implemented. Off Center details how "[c]ontrol of language and alternatives can be used to frame discussions in ways that exploit voters' lack of knowledge" (Hacker \& Pierson 2006, p. 67). Small benefits to average citizens are front loaded, while substantial benefits to the wealthy are phased in over time. "Republican policy initiatives," Hacker \& Pierson (2006, pp. 158-59) assert, "have been designed in ways that systematically place meager or doubtful benefits for average Americans prominent in the foreground while quietly showering the bulk of their largess on the attentive and well off." Ordinary citizens get their small tax cut immediately. Multimillionaires obtain their geometrically greater tax reduction over time. So-called moderate Republicans win plaudits from centrist voters by casting high-profile votes against more extreme programs. They win campaign contributions from affluent conservatives by remaining silent when Republican House and Senate conference committees quietly restore tax breaks and subsidies for the most fortunate Americans (Hacker \& Pierson 2006, p. 155). Not surprisingly, although the more affluent minority that benefits from Republican programs are able to identify correctly the provisions of crucial measures, surveys find that average citizens consistently misperceive crucial elements of legislation passed during recent years (Hacker \& Pierson 2006, p. 67).

The process by which conservative Republicans have secured unpopular policies suggests a further challenge to Bickel's framing of the countermajoritarian difficulty. Bickel recognized that some judicial decisions were consistent with majoritarian judgments. "The Court," he wrote, "represents the national will against local particularism" (Bickel 1962, p. 33). Nevertheless, Bickel promptly added, the Court "does not represent [the national will], as Congress does, through electoral responsibility." Judicial policymaking is wrong, in this view, because voters cannot hold lifetenured justices politically accountable for constitutional decisions popular majorities think mistaken. Regime politics theory questions this account, insisting that justices, or their 
political sponsors, are often more accountable than Bickel realized (Peretti 1999). Richard Nixon's campaign against the Warren Court demonstrates that Americans are capable of reversing the trend of judicial decisions when they are able to identify the political forces supporting unpopular rulings. Contemporary students of public law (Lovell \& Lemieux 2006; Whittington 2007, p. 295) claim that judicial review presents accountability problems only when politicians foist issues onto courts in ways that obscure their responsibility for the ultimate decision. Off Center recognizes that other governing institutions suffer from this countermajoritarian/accountability difficulty whenever responsibility for policymaking is difficult to discern. Hacker \& Pierson (2006, p. 17) remind scholars, "For democratic competition to work, voters need to be able to find out what politicians do and how it affects them." Americans cannot hold conservative Republicans accountable for unpopular conservative policies, their work claims, because they lack the information necessary to vote their policy preferences accurately. Politicians undemocratically "run from daylight" when they surreptitiously delegate issues to the courts, but also when they without fanfare reduce workplace safety and environmental inspections, prevent the implementation of new rules, and fail to demand significant damages for legal violations (Hacker \& Pierson 2006, pp. 93-100). Policymaking by justices whose political sponsors are identified may better promote political accountability, in this view, than executive orders known only to the most astute or compulsive observers of American politics.

\section{The Countermajoritarian Difficulty with the Constitution}

American electoral institutions also suffer from countermajoritarian difficulties that are constitutionally built into the polity. That the Constitution contains various majoritarian failings is hardly surprising. The persons responsible for the Constitution of 1787 were not unalloyed majoritarians, and they scorned democracy, at least what they referred to as democracy. ${ }^{3}$ Constitutional institutions were designed to "break and control the violence of faction," which Madison believed could consist of "a majority or a minority of the whole" (Hamilton et al. 1961, pp. 77-78). Still, that the framers were not majoritarian democrats is hardly a sufficient reason for more enlightened citizens to endorse countermajoritarian practices at present. Maintaining the Senate and the Electoral College seems particularly perverse. Dahl (2001, pp. 31, 49), the preeminent democratic theorist in the United States, asserts that the "electoral college...grossly violate(s) basic democratic principles" and that "the degree of unequal representation in the U.S. Senate is by far the most extreme" in the world. Both constitutional mandates are countermajoritarian, no longer fulfill their original constitutional purpose, arguably no longer fulfill any legitimate constitutional purpose, and privilege interests with no special call on extraordinary constitutional protection. The Senate and Electoral College both, for example, augment the political power of white citizens at the expense of persons of color (Dahl 2001, pp. 52-53; Lee \& Oppenheimer 1999, pp. 20-22).

Lee \& Oppenheimer (1999) elaborate the undemocratic and unfair consequences of equal state representation in the Senate. A model of political science inquiry, their Sizing Up the Senate: The Unequal Consequences of Equal Representation demonstrates how the framing decision in 1787 to guarantee each state equal representation in one chamber of the national legislature "leaves no aspect of the institution untouched" (Lee \& Oppenheimer 1999, pp. 224-25). Senators from small states have personal relationships with more of their constituents ( $p$. 54), they are more likely to limit fundraising to persons interested in obtaining particularized benefits from the national government (p. 84), and they are more likely to secure particularized

\footnotetext{
${ }^{3}$ Dahl (2001, pp. 159-62) argues that the framers opposed only direct democracy and generally favored modern representational democracy.
} 
benefits for their constituents (p. 13). Equal representation determines how federal funds are distributed, which partisan coalitions control the Senate, and how much power those coalitions exercise.

Small-state senators are particularly adept at bringing home the bacon for their constituents. Senators from low-population states almost always secure state minimums, typically $0.5 \%$ of the total funds allocated, whenever nondiscretionary federal spending programs are enacted (Lee \& Oppenheimer 1999, p. 205). Wyoming, for example, receives far greater funding per citizen than California for assistance to the blind, even though no evidence exists that a greater percentage of blind people reside in Wyoming or that blind people in Wyoming require more financial assistance. Small-state senators earn this bonanza for their constituents because senators with equal power naturally seek to secure equal benefits. "A 'fair' distribution in the Senate," Lee \& Oppenheimer $(1999$, p. 163) detail, "is one that treats all senators 'equitably,' tending toward an equal allocation of funds across states." Senators from low-population states also have greater capacity to obtain additional funds for their constituents as the price for supporting legislation. Because they need fewer votes for reelection, relatively small amounts of spending can secure the vote of a small-state senator. As one commentator noted, "[T]he small states are cheap dates" (Lee \& Oppenheimer 1999, p. 190).

Equal state representation structures nonspending policy by influencing the representational experience of senators, their capacity for leadership, and the partisan balance in the upper chamber of the national legislature. Senators from low-population states are freer to champion controversial positions on more issues than their peers from more populous states, Lee \& Oppenheimer (1999, p. 149) explain, because their constituencies are more homogenous and care about fewer issues. A North Dakota senator who increases agriculture subsidies may be immune from electoral reprisal for taking any plausible position in the contemporary war on terrorism. Senators from low-population states, who face fewer demands from their constituents, are also freer to seek Senate leadership positions. For the past 40 years, Democrats in the Senate have been led by representatives from Montana, West Virginia, Maine, South Dakota, and Nevada, even though the party's base hails primarily from urban communities (Lee \& Oppenheimer 1999, p. 151). Most significantly, equal state representation affects the partisan balance in the Senate. On some occasions, Lee \& Oppenheimer (1999, pp. 11516) demonstrate, a different party would have controlled the Senate had Americans been represented by population. More often, one party gained 3-4 seats by taking advantage of strength in small states. Interestingly, minority parties tend to benefit more from equal state representation in the Senate than majority parties (Lee \& Oppenheimer 1999, p. 120). This contrarian tendency may alternatively promote moderation, by empowering the most centrist members of the majority coalition, or stasis, by facilitating filibusters.

Democrats and Republicans have both taken advantage of equal state representation in the Senate. Democrats were the beneficiaries of this arrangement from 1914 to 1930 and from 1942 until 1958. Republicans have more commonly benefitted in recent years. Republican control of the Senate during the Reagan (Lee \& Oppenheimer 1999, p. 115) and George W. Bush administrations (Hacker \& Pierson 2006 , p. 36) was an artifact of the countermajoritarian constitutional rules for staffing that institution. Had Senate seats at the turn of the twenty-first century been allocated by population, the tax system in the United States would be a little more progressive, the welfare system a bit more generous, and Supreme Court justices less conservative than Clarence Thomas and Samuel Alito. Even if political coalitions based in more populous states are neither consistently liberal nor consistently conservative, a fair possibility exists that the politics of these jurisdictions have some common features. If, as Lee \& Oppenheimer so meticulously demonstrate, the representative experience of a small-state senator differs dramatically from the representative 
experience of a large-state senator, then perhaps political movements that flourish in large states have different characteristics than political movements that flourish in smaller states. At the very least, their analysis helps explain why New Deal Democrats were committed to providing subsidies for farmers, whereas Reagan Revolution Republicans exhibited little interest in ending that form of welfare.

State equality in the Senate is hardly the only countermajoritarian problem with the Constitution. When asked about a decade ago to discuss the "stupidest" provision in the Constitution, the democratic populist law professor Mark Tushnet responded, "The Whole Thing." His answer to that question was "[m]ost of Article I, much of Article II, a fair chunk of Article III, nearly all of Article VI, and many of the Amendments," a response Tushnet concluded was "equivalent to saying, 'Article V'" (Tushnet 1995, p. 224). Levinson's (2006) anticonstitutional polemic, Our Undemocratic Constitution, provides a more comprehensive attack on the U.S. Constitution as a legitimate foundation for democratic government. His grand tour of numerous constitutional provisions that frustrate popular majorities concludes that "it is increasingly difficult to construct a theory of democratic constitutionalism ... that vindicates the Constitution under which we are governed" (Levinson 2006, p. 6).

Levinson focuses his sharp gaze on such constitutionally mandated procedures as the presidential veto. These clauses, whose language is not subject to much interpretive flexibility, prevent popular majorities from passing legislation, vest too much power in a relatively irresponsible president, and allow tiny minorities to veto desperately needed constitutional reforms. The result is a government prone to the lethal combination of poor performance and poor accountability. Although Levinson is a democratic majoritarian, he points out that consensus democrats are no more likely to be happy with contemporary constitutional practice. "Structural provisions of the Constitution," he details, "place almost insurmountable barriers in the way of any acceptable notion of democracy" (Levinson 2006, p. 6).

Our Undemocratic Constitution (Levinson 2006, pp. 167-68) describes seven constitutional practices as "truly grievous defects." These constitutional abominations are state equality in the Senate, the lack of any constitutional provision for governance should a terrorist attack disable most members of Congress, the presidential veto power and absence of clear limits on executive power during emergencies, the Electoral College and general process for selecting the president, the relatively lengthy time period between the election and the inauguration of the president, the limitation on impeachments to "high crimes and misdemeanors," and the supermajoritarian requirements for constitutional amendment. These constitutional flaws all directly or indirectly promote countermajoritarian government. The process for electing and removing presidents enables persons to gain office without a popular majority and retain office for years in the face of hostile popular opinion. Article II, Levinson (2006, p. 117) bemoans, vests "a noncriminal president" with "an unbreakable four-year lease on the White House" (Levinson 2006, p. 117). The constitutional rules for making laws offer minorities numerous veto points that are used to frustrate the popular will. The presidential veto, in particular, is "just one more antimajoritarian feature of our Constitution that makes it ever harder to pass legislation departing from the status quo" (Levinson 2006, p. 44). Worst of all, the constitutional requirements for amendments inhibit all serious conversations about constitutional change. Levinson (2006, p. 21) notes how "Article $\mathrm{V}$ makes it next to impossible to amend the Constitution with regard to genuinely controversial issues, even if substantial — and intensemajorities advocate amendment."

Judicial power is the least of Levinson's concerns. He does include "life tenure for Supreme Court justices" under the heading "very real, even if not so dangerous" constitutional failings (Levinson 2006, p. 168). After noting that the "formative adult experiences" of elderly 
Supreme Court justices "took place forty years earlier in a society often unrecognizable in the present," Levinson (2006, p. 130) asserts, “[i]t is one thing to elect such individuals to govern," but "another to have them govern because elected individuals approved of them twenty or thirty years earlier." Levinson does not, however, criticize judicial review practiced by a court whose members serve 18 -year terms or by lower federal court justices whom he does not object to serving for life (Levinson 2006, p. 127). This last concession may be an oversight, given how rarely reviewed lower federal court decisions often practically determine the constitutional rights of the parties.

In ways he may not always acknowledge, Levinson is a constitutionalist and a democrat. Throughout the book he calls for a new constitutional convention. Our Undemocratic Constitution never notes the possibility, suggested by Klarman (1997), that democratic populists should dispense with constitutionalism. Levinson (2006) makes a sharp distinction between presidential vetoes on policy and constitutional grounds. He voices "no objection" to the latter, "even if it is unclear whether the president in such circumstances should be allowed the last word" (p. 45). How this distinction might function in practice is unclear. If presidents did not have to defer to legislative judgments that a spending bill promotes the "general welfare" or that pollution regulations are "necessary and proper means" for promoting interstate commerce, then policy vetoes might easily merge into constitutional vetoes. Regardless, Levinson seems to accept the notion of some constitutional constraint on elected officials, even if elected officials are responsible for interpreting those constraints.

This populist manifesto ends on a remarkably antipopulist note. Levinson (2006, pp. 174-75) repeatedly condemns intellectuals who are opposed to a new constitutional convention as "being close to terrified of the passions of their fellow citizens" and exhibiting "an utter lack of faith in the democratic potential of our fellow Americans." He condemns as vigorously the overwhelming majority of Americans, who credit the Constitution of the United States for American success (see Dahl 2001, pp. 122, 141). When virtually all his students defended a life-tenured judiciary on a final examination, Levinson (2006, p. 124) regarded this "absolutely inexplicable... commitment" as a consequence of "the 'veneration' accorded to the Constitution and all of its aspects, however dubious they may be." High Federalists could not have expressed their skepticism about the political capacities of ordinary Americans more succinctly.

Average citizens may express little interest in a constitutional convention in part because they suspect that the leaders in that convention will not differ significantly from the persons playing leadership roles in contemporary constitutional politics. Delegates selected consistently with contemporary political practices may have incentives to entrench polarization or the institutional foundations of that phenomenon. Of course, ordinary Americans might be wrong in their judgments about the Constitution or a constitutional convention. If Americans may be deluded about the Constitution, however, perhaps they may have other delusions that are perverting constitutional politics in the United States. Perhaps, as Hacker \& Pierson (2006) suggest, those other delusions may be having a more baneful influence on American constitutional politics than beliefs about the Constitution. Consider whether altering the Electoral College or abolishing the Senate would prevent the propaganda that convinced many Americans that Saddam Hussein was allied with al Qaeda or confused voters about the impact of recent tax cuts. Constitutional culture, if Hacker \& Pierson are right, may need reforming before constitutional law and constitutional courts can be successfully reformed.

Popular approval of both the Constitution and judicial review cast doubt on whether either is countermajoritarian. The countermajoritarian difficulty and the democratic attack on the Constitution treat democracy as a strict function of popular support for particular policies or for particular governing officials. Whether laws against abortion pass democratic muster, in this 
view, depends on whether a majority of Americans or a majority of elected representations in the United States believe abortion should be legally prescribed. Democracy, however, may entail the people's right to choose governing institutions, subject to important restrictions. Particular majorities may not dilute the political power of identifiable minorities. Most democratic theorists would not justify a constitution that vested absolute power in $53 \%$ of the population that was supported only by that privileged $53 \%$. Constitutional institutions supported by overwhelming majorities, by comparison, may be democratic, even when those institutions inhibit popular majorities, often for what seem to scholars to be dubious reasons. Levinson might point out that Americans are not asked to vote on the Constitution or judicial review, though arguably the nomination process for Supreme Court justices provides a forum for debating how the power of judicial review should be exercised. Still, given the overwhelming support Americans seem to have for both the Constitution and judicial review, as well as their belief that other issues are more important (Hacker \& Pierson 2006, p. 192), demanding scarce political time and resources be spent submitting the Constitution and judicial review to a referendum might be, well, countermajoritarian.

\section{THE COUNTERMAJORITARIAN DIFFICULTY REVISED}

The countermajoritarian difficulty suffers from normative and institutional myopia. Bickel and his followers focused obsessively on majoritarianism, ignoring other democratic problems that may be aggravated or ameliorated by judicial decisions declaring laws unconstitutional. Constitutional commentators reared on The Least Dangerous Branch isolated courts from other governing institutions, ignoring how judicial power is largely determined by decisions made (or not made) by elected officials and is unlikely to be responsive to reform efforts until presidents and members of Congress change their behaviors. The works surveyed in this review provide foundations for the more com- prehensive institutional and normative analysis necessary for creating and maintaining a constitutional democracy (Murphy 2007 is a model of such analysis). Each study, in different ways, examines how constitutions structure interactions between governing institutions, often in ways that help secure some democratic goods at the expense of others.

Majoritarianism is only one of many democratic commitments. Good democracies seek policies that are coherent, appeal to most citizens, and are capable of being revised by popular acclaim. Judicial decisions that do not present classic countermajoritarian difficulties may present coherence, polarization, and accountability difficulties. Politically constructed judicial review that does not "thwart the will" of the people's elected representatives may undermine policy decisions made elsewhere in the political system, antagonize crucial voting blocs, and obscure responsibility for policymaking. Politically constructed judicial review also presents bias difficulties. All forms of political empowerment structure public policy. The Federal Reserve Board relies on different decision-making metrics than the House Banking Committee. The budget for the local library depends on whether funding is allocated by the town council, the county board of supervisors, the state legislature, or the Congress of the United States. Granting courts the power to declare laws unconstitutional similarly changes political dynamics, privileging some political interests at the expense of others (Hirschl 2004, pp. 12-14; Graber 2006a, pp. 691-95). Judicial review that passes democratic muster may nevertheless be undesirable if a different practice would protect interests with a better claim to political or constitutional solicitude.

Studies of the countermajoritarian, coherence, polarization, accountability, and bias difficulties should be concerned with the performance of the constitutional system as a whole, abandoning an "institutional partisanship" that assumes "the centrality of the[ ] [particular] institution" being studied "in the drama of American politics" (Tulis 1987, pp. 9-10). Whether justices should behave consistently 
with a predetermined script depends on whether other political actors are behaving consistently with their predetermined scripts. Judicial decisions that in an ideal world aggravate democratic deficits may promote democracy when the practical alternative is gridlock or when elected officials publicly identify and take responsibility for the judicial choice. If, as Whittington (2007) and Frymer (2007) maintain, presidents and national legislators frequently have powerful incentives to foster judicial policymaking, judicial behavior is likely to be reformed only when elected officials have greater inducements for making constitutional decisions on their own. If, as Hacker \& Pierson (2006), Lee \& Oppenheimer (1997), and Levinson (2006) claim, elected officials can no longer claim the mantle of democratic legitimacy, resolving the most important countermajoritarian difficulties in American politics requires serious political and constitutional reform, not better constitutional interpretation.

The resulting constitutional theories are likely to be more complex than those generated by the countermajoritarian difficulty. Bickel and his followers assumed that judicial decisions declaring laws unconstitutional were inherently countermajoritarian. In practice, whether judicial review presents countermajoritarian, coherence, polarization, accountability, and bias difficulties varies by case and is often contestable. Brown v. Board of Education (1954) was more polarizing that Planned Parenthood v. Casey (1992). Casey presented greater accountability difficulties than Brown, given that Republican judicial appointees supported the constitutional right to abortion. The judicial decisions desegregating labor unions made civil rights law more coherent and labor law less coherent. Whether justices have a special capacity to "listen to voices from the margins" (Fiss 1989, p. 255) or privilege affluent interests (Hirschl 2004) is a matter of debate.

The countermajoritarian and other difficulties are not for law professors only. How courts respond to constitutional conflicts is largely structured by electoral politics. That electoral politics, in turn, is often wracked with countermajoritarian, coherence, polarization, accountability, and bias difficulties is partly rooted in constitutionally mandated procedures. These democratic deficits require rethinking basic institutional practices in the United States and are largely immune to constitutional law. Work on the political construction of judicial power facilitated fruitful dialogues on the role of the judiciary in a constitutional democracy between academic lawyers and political scientists who taught public law. As the countermajoritarian and other difficulties continue migrating from the courts to the Congress to the constitutional culture, the time has come to bring students of American and comparative politics into the conversation.

\section{DISCLOSURE STATEMENT}

The author is not aware of any biases that might be perceived as affecting the objectivity of this review.

\section{LITERATURE CITED}

Abramowitz A, Saunders K. 2005. Why can't we all just get along? The reality of a polarized America. Forum $3(2): 1-21$

Agresto J. 1984. The Supreme Court and Constitutional Democracy. Ithaca, NY: Cornell Univ. Press

Alexander L, Schauer F. 1997. On extrajudicial constitutional interpretation. Harvard Law Rev. 110:1359-87

Am. Polit. Sci. Assoc. 1950. Toward a more responsible two-party system: a report of the committee on political parties. Am. Polit. Sci. Rev. 44(3):Part 2, Suppl.

Balkin JM, Levinson S. 2001. Understanding the constitutional revolution. Va. Law Rev. 87:1045-109

Bickel AM. 1962. The Least Dangerous Branch: The Supreme Court at the Bar of Politics. Indianapolis: Bobbs-

Merrill 
Brown v. Board of Education, 347 U.S. 483 (1954)

Buckley v. Valeo, 424 U.S. 1 (1976)

Burgess SR. 1992. Contest for Constitutional Authority: The Abortion and War Powers Debates. Lawrence: Univ. Press Kans.

Carsey TM, Layman GC. 2005. "Conflict extension" in American party politics. Vox Pop Newsl. Polit. Organ. Parties 24(1):1, 6-7

Chayes A. 1976. The role of the judge in public law litigation. Harvard Law Rev. 89:1281-316

Choper JH. 1980. Fudicial Review and the National Political Process: A Functional Reconsideration of the Role of the Supreme Court. Chicago: Univ. Chicago Press

Clayton CW, May D. 1999. The new institutionalism and Supreme Court decision making: toward a political regimes approach. Polity 32:233-52

Clayton CW, Pickerill JM. 2009. The Supreme Court in the Political Regime: How Politics Structures the Exercise of fudicial Review. Chicago: Univ. Chicago Press

Curtis MK. 2000. Free Speech, "The People's Darling Privilege": Struggles for Freedom of Expression in American History. Durham, NC: Duke Univ. Press

Dahl RA. 1957. Decision-making in a democracy: the Supreme Court as a national policymaker. 7. Public Law 6:279-95

Dahl RA. 1961. Who Governs? Democracy and Power in an American City. New Haven, CT: Yale Univ. Press

Dahl RA. 2001. How Democratic is the American Constitution? New Haven, CT: Yale Univ. Press

Delgado R, ed. 1995. Critical Race Theory: The Cutting Edge. Philadelphia, PA: Temple Univ. Press

Devins N. 1996. Shaping Constitutional Values: Elected Government, the Supreme Court, and the Abortion Debate. Baltimore, MD: Johns Hopkins Univ. Press

Dinan JJ. 1998. Keeping the People's Liberties: Legislators, Citizens, and fudges as Guardians of Rights. Lawrence: Univ. Press Kans.

Dred Scott v. Sandford, 60 U.S. 393 (1856)

Ellis RE. 1971. The Feffersonian Crisis: Courts and Politics in the Young Republic. New York: Oxford Univ. Press Ely JH. 1980. Democracy and Distrust: A Theory of Judicial Review. Cambridge, MA: Harvard Univ. Press

Fiorina MP, Abrams SJ, Pope JC. 2005. Culture War? The Myth of a Polarized America. New York: Pearson Longman

Fisher L. 1988. Constitutional Dialogues: Interpretation as Political Process. Princeton, NJ: Princeton Univ. Press

Fiss OM. 1979. Foreword: the forms of justice. Harvard Law Rev. 93:1-58

Fiss OM. 1989. The law regained. Cornell Law Rev. 74:245-55

Friedman B. 1993. Dialogue and judicial review. Mich. Law. Rev. 91:577-682

Friedman B. 1998. The history of the countermajoritarian difficulty, Part One: The road to judicial supremacy. N.Y. Univ. Law Rev. 73:333-433

Friedman B. 2000. The history of the countermajoritarian difficulty, Part Four: Law's politics. Univ. Penn. Law Rev. 148:971-1064

Friedman B. 2001. The history of the countermajoritarian difficulty, Part Three: The lesson of Lochner. N.Y. Univ. Law Rev. 76:1383-455

Friedman B. 2002a. The birth of an academic obsession: the history of the countermajoritarian difficulty, Part Five. Yale Law 7. 112:153-259

Friedman B. 2002b. The history of the countermajoritarian difficulty, Part II: Reconstruction's political court. Georget. Law 7. 91:1-65

Friedman B. 2005. The politics of judicial review. Tex. Law Rev. 84:257-337

Friedman B. 2009. The Will of the People. New York: Farrar, Straus and Giroux

Frymer P. 2003. Acting when federal officials won't: federal courts and civil rights enforcement in U.S. labor unions 1935-1985. Am. Polit. Sci. Rev. 97:483-99

Frymer P. 2007. Black and Blue: African Americans, the Labor Movement, and the Decline of the Democratic Party. Princeton, NJ: Princeton Univ. Press

Gillman H. 2002. How political parties can use the court to advance their agendas: federal courts in the United States, 1875-1891. Am. Polit. Sci. Rev. 96:511-24 
Gillman H. 2006. Party politics and constitutional change: the political origins of liberal judicial activism. In The Supreme Court and American Political Development, ed. K Kersch, R Kahn, pp. 138-68. Lawrence: Univ. Press Kans.

Ginsberg B, Shefter M. 1990. Politics by Other Means: The Declining Importance of Elections in America. New York: Basic Books

Ginsburg T. 2003. Judicial Review in New Democracies: Constitutional Courts in Asian Cases. New York: Cambridge Univ. Press

Graber MA. 1993. The nonmajoritarian difficulty: legislative deference to the judiciary. Stud. Am. Polit. Dev. $7: 35-73$

Graber MA. 1997. The Clintonification of American law: abortion, welfare, and liberal constitutional theory. Obio St. Law 7. 58:731-818

Graber MA. 2001. Social democracy and constitutional theory: an institutional perspective. Fordham Law Rev. 69:1969-87

Graber MA. 2005. Constructing judicial review. Annu. Rev. Polit. Sci. 8:425-51

Graber MA. 2006a. Does it really matter? Conservative courts in a conservative era. Fordham Law Rev. 75:675708

Graber MA. 2006b. Dred Scott and the Problem of Constitutional Evil. New York: Cambridge Univ. Press

Greenberg SB. 1996. Middle Class Dreams: The Politics and Power of the New American Majority. New Haven, CT: Yale Univ. Press

Griffin SM. 1996. American Constitutionalism: From Theory to Politics. Princeton, NJ: Princeton Univ. Press

Hacker JS, Pierson P. 2006. Off Center: The Republican Revolution and the Erosion of American Democracy. New Haven, CT: Yale Univ. Press

Hamilton A, Madison J, Jay J. 1961. The Federalist Papers, ed. C Rossiter. New York: New Am. Libr.

Hirschl R. 2004. Toward furistocracy: The Origins and Consequences of the New Constitutionalism. Cambridge, MA:

Harvard Univ. Press

Horowitz DL. 1977. The Courts and Social Policy. Washington, DC: Brookings

Jefferson T. 1975. The Portable Thomas fefferson, ed. MD Peterson. New York: Penguin

Klarman MJ. 1997. Antifidelity. S. Calif. Law Rev. 70:381-415

Klarman MJ. 2004. From fim Crow to Civil Rights: The Supreme Court and the Struggle for Civil Rights. New York: Oxford Univ. Press

Kramer LD. 2004. The People Themselves: Popular Constitutionalism and fudicial Review. New York: Oxford Univ. Press

Lasser W. 1988. The Limits of fudicial Power: The Supreme Court in American Politics. Chapel Hill, NC: Univ. N. C. Press

Lee FE, Oppenheimer BI. 1999. Sizing Up the Senate: The Unequal Consequences of Equal Representation. Chicago: Univ. Chicago Press

Levinson S. 1988. Constitutional Faith. Princeton, NJ: Princeton Univ. Press

Levinson S. 2006. Our Undemocratic Constitution: Where the Constitution Goes Wrong (and How We the People Can Correct It). New York: Oxford

Lovell GI. 2003. Legislative Deferrals: Statutory Ambiguity, fudicial Power, and American Democracy. New York: Cambridge Univ. Press

Lovell GI, Lemieux SE. 2006. Assessing juristocracy: Are judges rulers or agents? Md. Law Rev. 65:100-14

Lowi TJ. 1969. The End of Liberalism: Ideology, Policy, and the Crisis of Public Authority. New York: Norton

Mann TE, Ornstein NJ. 2006. The Broken Branch: How Congress Is Failing America and How to Get It Back on Track. New York: Oxford Univ. Press

Marbury v. Madison, 5 U.S. 137 (1803)

Matsuda MJ, Lawrence CR III, Delgado R, Crenshaw KW, eds. 1993. Words that Wound: Critical Race Theory, Assaultive Speech, and the First Amendment. Boulder, CO: Westview

McCarty N, Poole KT, Rosenthal H. 2006. Polarized America: The Dance of Ideology and Unequal Riches. Cambridge, MA: MIT Press

McCloskey RG. 2005. The American Supreme Court, rev. S Levinson. Chicago: Univ. Chicago Press. 4th ed.

McMahon KJ. 2004. Reconsidering Roosevelt on Race: How the Presidency Paved the Road to Brown. Chicago: Univ. Chicago Press 
McMahon KJ. 2008. Nixon's Court: The Silent Majority and the Conservative Counterrevolution That Was. Chicago: Univ. Chicago Press

Meese E. 1987. The law of the Constitution. Tulane Law Rev. 61:979-90

Murphy WF. 2007. Creating and Maintaining a fust Political Order. Baltimore, MD: Johns Hopkins Univ. Press Orren K, Skowronek S. 2004. The Search for American Political Development. New York: Cambridge Univ. Press Peretti TJ. 1999. In Defense of a Political Court. Princeton, NJ: Princeton Univ. Press

Pickerill JM, Clayton CW. 2004. The Rehnquist Court and the political dynamics of federalism. Perspect. Polit. 2:233-48

Planned Parenthood of Southeastern Pennsylvania v. Casey, 505 U.S. 833 (1992)

Polsby NW. 2004. How Congress Evolves: Social Bases of Institutional Change. New York: Oxford Univ. Press

Powe LA. 2000. The Warren Court and American Politics. Cambridge, MA: Harvard Univ. Press

Roe v. Wade, 410 U.S. 113 (1973)

Rosen J. 2006. The Most Democratic Branch: How Courts Serve America. New York: Oxford Univ. Press

Rosenberg GN. 1991. The Hollow Hope: Can Courts Bring About Social Change? Chicago: Univ. Chicago Press

Shapiro M. 1966. Freedom of Speech: The Supreme Court and fudicial Review. Englewood Cliffs, NJ: PrenticeHall

Silverstein G. 2009. Law's Allure: How Law Shapes, Constrains, Saves and Kills Politics. New York: Cambridge Univ. Press

Skowronek S. 1982. Building a New American State: The Expansion of National Administrative Capacities, $1877-$ 1920. New York: Cambridge Univ. Press

Skowronek S. 1993. The Politics Presidents Make: Leadership From fohn Adams to George Bush. Cambridge, MA: Harvard Univ. Press

Skowronek S. 2008. Presidential Leadership in Political Time: Reprise and Reappraisal. Lawrence: Univ. Press Kans.

Sweet AS. 2000. Governing with fudges: Constitutional Politics in Europe. New York: Oxford Univ. Press

Tate CN, Vallinder T, eds. 1995. The Global Expansion of Judicial Power. New York: N.Y. Univ. Press

Tulis JK. 1987. The Rhetorical Presidency. Princeton, NJ: Princeton Univ. Press

Tushnet M. 1995. The whole thing. Const. Comment. 12:223-25

Tushnet M. 2006. The Supreme Court and the national political order: collaboration and confrontation. In The Supreme Court and American Political Development, ed. K Kersch, R Kahn, pp. 117-37. Lawrence: Univ. Press Kans.

Tushnet MV. 2005. A Court Divided: The Rebnquist Court and the Future of Constitutional Law. New York: Norton

Warren C. 1913. Legislative and judicial attacks on the Supreme Court of the United States-a history of the twenty-fifth section of the Judiciary Act. Am. Law Rev. 47:1-34, 161-89

Warren E. 1977. The Memoirs of Earl Warren. Garden City, NY: Doubleday

Whittington KE. 2005. "Interpose your friendly hand": political supports for the exercise of judicial review by the United States Supreme Court. Am. Polit. Sci. Rev. 99:583-96

Whittington KE. 2007. Political Foundations of Judicial Supremacy: The Presidency, the Supreme Court, and Constitutional Leadership in U.S. History. Princeton, NJ: Princeton Univ. Press 